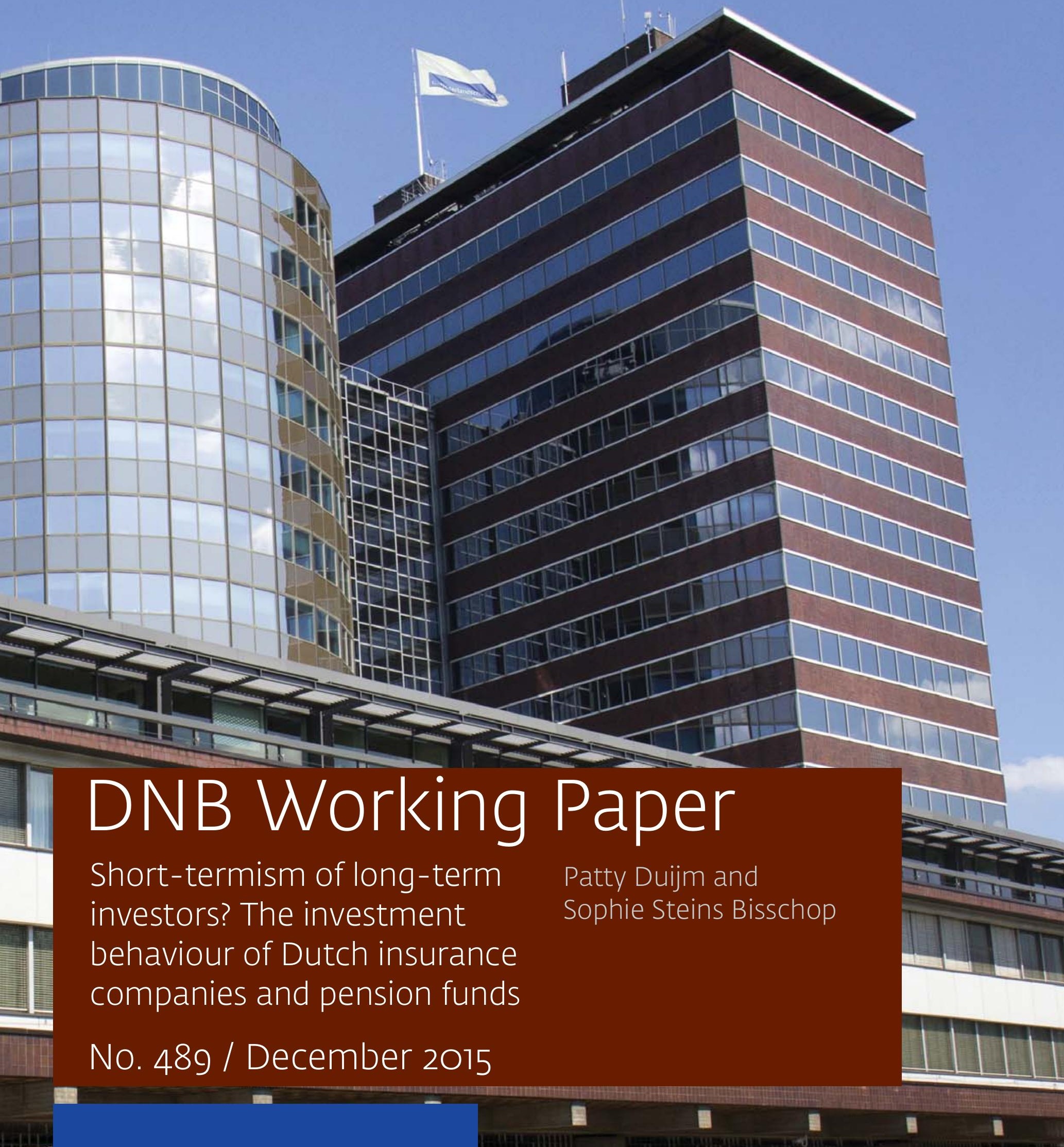

DeNederlandscheBank $(-2, j$

\title{
EUROSYSTEEM
}




\section{Short-termism of long-term investors? The investment behaviour of Dutch insurance companies and pension funds}

Patty Duijm and Sophie Steins Bisschop*

* Views expressed are those of the authors and do not necessarily reflect official positions of De Nederlandsche Bank.

Working Paper No. 489

December 2015
De Nederlandsche Bank NV

P.O. Box 98

$1000 \mathrm{AB}$ AMSTERDAM

The Netherlands 


\title{
Short-termism of long-term investors? The investment behaviour of Dutch insurance companies and pension funds*
}

\author{
Patty Duijm ${ }^{\mathrm{a}}$ and Sophie Steins Bisschop ${ }^{\mathrm{b}}$ \\ ${ }^{a}$ De Nederlandsche Bank, Financial Stability Division, PO BOX 98, NL-1000 AB, Amsterdam, \\ p.duijm@dnb.nl. \\ ${ }^{b}$ De Nederlandsche Bank, Financial Stability Division, PO BOX 98, NL-1000 AB, Amsterdam, \\ s.a.steins.bisschop@dnb.nl.
}

November 2015

\begin{abstract}
Countercyclical long-term investment strategies of insurance companies and pension funds (ICPFs) can support the stability of the financial system. Yet there is limited understanding of how ICPFs invest during market shocks, such as the global financial crisis and the European sovereign debt crisis. The intention of this paper is to fill that lacuna by investigating Dutch ICPFs' equity and sovereign bond portfolios. A first analysis shows that while ICs massively sold equities during the crisis, PFs kept buying equities as markets tumbled. Results from our regression analysis over a longer time horizon suggest procyclical behaviour by ICs, while for PFs we do not find evidence for procyclical or countercyclical investment behaviour. Moreover, both ICs and PFs sold their affected sovereign bonds prior to a rating downgrade. This could be considered as destabilising at a macro-level, as it may accelerate the deteriorating financing conditions of the affected countries.
\end{abstract}

Keywords: microprudential, macroprudential, investment behaviour, pension funds, insurance companies, procyclicality, Solvency II, global financial crisis.

JEL classification: E44, G01, G11, G22, G28.

\footnotetext{
${ }^{*}$ We are grateful to Paul Witteman for assistance with data collection. We thank Dirk Broeders, Jon Frost, Robert Vermeulen, Arco van Oord, Tijmen Daniëls, and participants of the EIOPA Advanced Seminar on Quantitative Techniques for Financial Stability for valuable comments.
} 


\section{Introduction}

"Like bankers, institutional investors have risen and fallen with the herd." (Haldane, 2014)

A question of long-standing interest to both academics and policy makers is whether institutional investors such as insurance companies and pension funds (ICPFs) have a stabilising impact on financial markets. With rapidly growing assets under management, they have the potential to either stabilise or amplify swings in financial markets and the wider economy. Theoretically, ICPFs are expected to act as shock absorbers in times of financial stress, as their long-term investment horizon enables them to endure short-term price movements. Moreover, in contrast to for example banks and open end mutual funds, ICPF's liabilities can not easily be withdrawn and thereby they face no direct selling pressure from their policy holders. ICPFs also use rebalancing strategies. This implies "buy low, sell high, " i.e. when markets drop, they buy more equities or bonds to keep their equity or bond exposure at the desired level determined by their long-term strategic asset allocation strategy. Conversely, rebalancing means that ICPFs are expected to sell equities or bonds when prices have gone up. At a macro level, this strategy tempers both upward and downward movements, benefiting financial stability.

In practice, however, ICPFs may act differently, particularly in times of stress. During the global financial crisis, investors closed their positions in falling markets on a massive scale, further accelerating downward price movements. Several new studies analyse the investment behaviour of international ICPFs (see for example Papaioannou et al., 2013; Bank of England, 2013). While some studies provide indications for procyclical behaviour by ICPFs, the results are often mixed.

With assets under management of respectively $78 \%$ and $190 \%$ of Dutch GDP, ICs and PFs have the potential to influence market prices and the broader economy, and are thereby relevant from a systemic perspective. Using a unique dataset, we test whether Dutch ICPFs invested procyclically in the last nine years (2006Q1-2015Q1). We contribute to previous research by posing the following research questions: did Dutch ICPFs behave procyclically during and after the global financial crisis and European sovereign debt crisis? Specifically, did they: (i) sell or buy equities in line with market movements, and (ii) sell sovereign bonds around rating downgrades?

Our results are mixed. We find some evidence for procyclical behaviour as Dutch ICPFs sold sovereign bonds right before rating downgrades: they sold around $10 \%$ of initial exposures in the two quarters prior to the downgrade. Regarding equity portfolios, PFs acted countercyclically by buying equities right after the start of the global financial crisis. As markets kept tumbling, they eventually engaged in large equity sales, but in aggregate they purchased equities over the period 2007-2009.

ICs, on the contrary, sold large amounts of equities during both financial crisis episodes. This behaviour cannot be characterised immediately as 'strongly procyclical', since it may have structural causes. In anticipation of the new regulatory framework Solvency II, which will be implemented from 2016 onwards, Dutch ICs have been replacing parts of their equity portfolio by less risky assets, such as government bonds. The increased pressure on their business model could also have initiated a shift away 
from equities. While it is unclear whether net equity sales are driven by structural choices, it remains remarkable that ICs initiated large equity sales right after the outbreak of the global financial crisis.

Results from regression analyses confirm procyclical investment behaviour by ICs. When equities underperformed (outperformed) other assets they sold (bought) equities. This relationship is stronger after equity underperformance and during the global financial crisis. For PFs, we do not find any evidence for procyclical or countercyclical investment behaviour.

The remaining of this paper is organised as follows. Section 2 presents a review of the academic literature on triggers and evidence for procyclical behaviour. Section 3 makes a first assessment of the investment behaviour of Dutch ICPFs during the global financial and European sovereign debt crisis. Section 4 describes the data and research methodology and presents the results of the regression analysis. Section 5 concludes by exploring policy responses and suggestions for further research.

\section{Literature Review}

Before embarking on the empirical analysis, this section places our study in the context of the academic literature by focusing on three aspects of procyclicality: i) its (systemic) consequences; ii) potential drivers and iii) previous (international) evidence of such behaviour.

\subsection{Consequences of procyclical investment behaviour}

As providers of long-term financing, institutional investors such as ICPFs fulfill an important role in the real economy. For example, European ICPFs hold almost 30\% of the outstanding European corporate bonds, and Dutch ICPFs own approximately a quarter of the total Dutch government debt (see Table 1). ICPFs' investment behaviour could therefore influence the stability of market prices and funding conditions for governments, companies and the financial sector. Academics and policy makers ${ }^{2}$ confirm that procyclical investment behaviour by a few large or many small ICPFs hurts the stability of the overall financial system. It intensifies market volatility, which, in turn, may affect the real economy directly through losses on investments or indirectly through supply and demand factors.

Besides ICPFs' impact on financial markets and funding conditions, shocks to ICPFs may also harm economic growth through several other channels, for example when PFs curtail pension rights or increase contributions, or when ICs fail. All these elements could occur at the same time, but could also balance each other out. For example, a PF may sell equities in falling markets to avoid curtailments of pension rights or a rise in contributions. ICs could also invest procyclically to avoid failure, thereby both negatively and positively affecting the real economy. This paper only focusses on the first impact channel on the real economy by assessing whether ICPFs have a stabilising or destabilising role in financial markets.

\footnotetext{
${ }^{2}$ Relevant studies include Borio et al. (2001); Joint FSF-CGFS working group (2009); Papaioannou et al. (2013); Claessens and Kose (2013) and Houben and van Voorden (2014).
} 
Table 1: ICPFs' holdings of European bonds in \% of total issued bonds

Holdings of European and Dutch bonds by European and Dutch ICPFs in 2015Q1.

\begin{tabular}{lccccc}
\hline & $\begin{array}{c}\text { European } \\
\text { corporate bonds }\end{array}$ & $\begin{array}{c}\text { European } \\
\text { bank bonds }\end{array}$ & $\begin{array}{c}\text { Dutch } \\
\text { corporate bonds }\end{array}$ & $\begin{array}{c}\text { Dutch } \\
\text { bank bonds }\end{array}$ & $\begin{array}{c}\text { Dutch } \\
\text { gov. bonds }\end{array}$ \\
European ICPFs & $28.9 \%$ & $11.2 \%$ & $24.3 \%$ & $11.8 \%$ & n/a \\
Dutch ICPFs & $1.5 \%$ & $0.4 \%$ & $3.3 \%$ & $1.2 \%$ & $23.8 \%$ \\
\hline Source: $E C B-S H S$ & & & & &
\end{tabular}

Source: ECB-SHS

Short-term procyclical investment strategies are not only harmful for the overall financial system, they could also worsen the performance of individual institutions. If long-term investors deviate from their strategic 'buy low, sell high' rebalancing strategies, they may face higher transaction costs and lower returns, as argued by a study of the Bank of England (2013). Several other studies (Blake et al., 1999; Brinson et al. 1991; Daniel et al., 1998) also demonstrate that PFs' performance worsened when they exploited market timing strategies, meaning that they would have booked better results if they had followed their long-term investment strategies. Therefore, from both an institution's and a system-wide perspective, it seems beneficial if ICPFs apply long-term countercyclical strategies. In some situations, however, procyclical behaviour could be rational or even profitable for a single institution, even as it negatively impacts the market - an example of a coordination failure within the sector. The following section discusses these (rational) triggers for procyclical behaviour.

\subsection{Drivers of procyclical investment behaviour}

There is a large body of academic literature on the rationale behind procyclical investment behaviour by long-term investors. Many authors argue that long-term investors have a tendency to herd which, in turn, could indirectly induce procyclicality. Keynes (1936) already noticed that single institutions are wary of acting against the herd, because they may damage their reputation if they are the only institution performing badly while many others are booking good results. Bad performance, on the other hand, is easier to explain when an institution's peers made similar 'wrong' assumptions.

Scharfstein and Stein (1990) confirm that long-term investors engage in 'reputational herding.' They also list the so-called information cascade and compensation schemes as triggers for herding behaviour. The information cascade implies that investors believe that other market participants have superior information and that their invesment strategy reveals this information. Compensation schemes may trigger herding behaviour if investors are subjected to relative performance benchmarks. These benchmarks reward those institutions that have been historically more successful than others, forming a barrier to deviate from peers. Rajan (2005) also emphasizes that relative performance benchmarks create an incentive to herd which, in turn, may move asset prices away from fundamentals.

Herding behaviour could be procyclical when the herd moves together with the market. 
Papaioannou et al. (2013) identify five direct drivers of procyclicality:

i. Liquidity needs during times of stress: ICPFs may need to raise cash by selling assets in market downturns due to an underestimation of liquidity risks in good times. Beber et al. (2009) confirm that bond investors chase liquidity rather than credit quality during market stress.

ii. Risk models and forecasting errors: Traditional risk and forecasting models seem to have difficulties in identifying periods of severe stress, particularly when market movements eclipse anything seen in the recent past. Moreover, some widely applied risk measurement models stimulate procyclical investment behaviour. For example, the use of historical data on volatility, e.g. in value-at-risk models $(\mathrm{VaR})$, may cause the perception of risk to increase as actual volatility rises.

iii. Principal-agent problems: Asset managers could have incentives to focus on short-term performance instead of sticking to a long-term strategy. ICPFs (principal) use several measures, such as annual performance targets and benchmarks, to align their interests with those of asset managers (agent). These measures could have unintended consequences. Investment mandates, for example, may exacerbate procyclicality by using peer group benchmarks or strict rating restrictions.

iv. Disclosure and reporting requirements: Frequent reporting may reduce the investment horizon due to a stronger focus on annual or quarterly results, potentially inducing procyclicality. On the other hand, reporting could also be an important tool to clearly communicate to investors why an institution sticks to its long-term investment strategy and acts against the procyclical herd in times of market stress.

v. Regulation and market conventions: In general, regulatory flexibility during crises enhances countercyclical investment behaviour. Recently, both the national regulatory framework for PFs and the European regulatory framework for ICs were updated. For ICs, the EU Solvency II Directive will be implemented in 2016 and has several countercyclical components, such as the volatility adjustment for calculating capital requirements and the possibility to extend recovery periods in exceptional circumstances (Table 2). Dutch PF regulation also contains countercyclical elements, i.e. a relatively long recovery period and the ability to keep risk profiles at the pre-insolvency strategic level. At the same time, both regulatory regimes also have procyclical features, such as rating-dependent capital requirements for fixed income investments and strict mark-to-market valuation. Procyclicality can also be triggered by market conventions. Reliance on credit ratings in mandates may cause large swings in holdings around upgrades and downgrades, particularly when these are near the border of investment grade. Moreover, given the widespread use of the same small group of risk management models, large groups of investors could perceive risks to be rising at the same time, possibly triggering procyclical herding. 
Table 2: Overview of relevant Dutch ICPFs regulation

$\downarrow$ indicates procyclical, $\uparrow$ countercyclical and $\rightarrow$ no clear pro- or countercyclical incentives.

\begin{tabular}{|c|c|c|}
\hline & Pension funds (nFTK)* & Insurers (Solvency II) \\
\hline $\begin{array}{l}\text { Consequences } \\
\text { of insolvency }\end{array}$ & $\begin{array}{l}\rightarrow \text { PFs have to set up recovery plans } \\
\uparrow \text { During the recovery period, they are not } \\
\text { obliged to lower their risk profile } \\
\rightarrow \text { But they cannot increase the riskiness of } \\
\text { their investments above strategic targets }\end{array}$ & $\begin{array}{l}\rightarrow \text { ICs have to set up recovery plans } \\
\downarrow \text { During the recovery period, they are } \\
\text { obliged to } l o w e r \text { the risk profile of } \\
\text { investments } \text { or attract extra capital }\end{array}$ \\
\hline Recovery period & 个 Relatively long: $5-15$ years & $\begin{array}{l}\downarrow \text { Relatively short: } 6-9 \text { months } \\
\uparrow \text { Recovery period could be extended to } 7 \\
\quad \text { years in exceptional (market) circumstances }\end{array}$ \\
\hline $\begin{array}{l}\text { Capital requirements } \\
\text { for equity }\end{array}$ & $\begin{array}{l}\rightarrow \text { Mostly independent of financial cycle } \\
\text { (except for interest rate shocks) }\end{array}$ & $\begin{array}{l}\text { 个 Dependent on financial cycle (volatility } \\
\text { adjustment) }\end{array}$ \\
\hline $\begin{array}{l}\text { Capital requirements } \\
\text { for fixed income }\end{array}$ & \multicolumn{2}{|c|}{$\begin{array}{l}\downarrow \text { Partly dependent on rating and duration for both ICs and PFs } \\
\uparrow \text { European government bonds (denominated in EUR) have a risk weight of zero for both } \\
\text { sectors (downgrades do not lead to additional capital requirements) }\end{array}$} \\
\hline $\begin{array}{l}\text { Regulation on asset } \\
\text { allocation }\end{array}$ & \multicolumn{2}{|c|}{$\begin{array}{l}\text { 个 Prudent person rule applies for both ICPFs; there are no 'hard' limits on asset allocation } \\
\downarrow \text { But ICPFs can apply (rating / allocation) limits in their own mandates }\end{array}$} \\
\hline Valuation & $\begin{array}{l}\downarrow \text { ICPFs have to apply mark-to-market ac } \\
\uparrow \text { Liabilities are less sensitive to market } \mathrm{v}\end{array}$ & $\begin{array}{l}\text { ting for their assets } \\
\text { fluctuations (due to the ultimate forward rate) }\end{array}$ \\
\hline
\end{tabular}

\subsection{International evidence for procyclical investment behaviour}

Several studies analyse ICPFs' footprints in major market events. According to a study by the IMF (Papaioannou et al., 2013) US, Portugese and Spanish PFs engaged in equity sell offs in 2007-2008, which could be considered as destabilising given the market circumstances at that time. On the other hand, PFs in Norway, Italy, Poland, and Turkey reacted countercyclically by purchasing equity during the market downturn and lowering the intensity of the purchases as markets recovered. The Bank of England (2013) also finds evidence from the global financial crisis for both countercyclical and procyclical investment behaviour by PFs. The authors conclude that they invested countercyclically in the short run and procyclically in the medium run, but that the decision to sell equities was also triggered by the desire to structurally adopt safer investment strategies. Blake et al. (2015) analyse the behaviour of UK PFs over a much longer time period ( 25 years) and conclude that they did not have a stabilising effect on markets, as they only applied rebalancing in the short run. The authors also find strong evidence for herding behaviour among PFs.

Regarding ICs, a recent study by the BIS (Domanski et al., 2015) finds that duration chasing by German life ICs intensified the drop in euro area bond yields in 2014. Impavido and Tower (2009) point out that US life ICs contributed to the market crash in 2001-2003 (dotcom bubble) by selling equities in falling markets. During the global financial crisis they observe a similar pattern, albeit to a lesser extent. Rudolph (2011), however, does not find evidence for procyclical investment strategies of US life ICs in the longer run. His study shows that they kept their investment mix relatively stable over the period 2001-2011. The Bank of England (2013) finds a positive correlation between the equity investments of US, UK and French life ICs and stock market perfomance over the period 1996-2012. However, the authors do not draw strong conclusions from these findings due to data limitations and the fact that there 
was a structural shift towards more conservative asset allocations.

\subsection{Evidence for procyclical investment behaviour of Dutch ICPFs}

The investment behaviour of Dutch PFs has been analysed both before and right after the outbreak of the global financial crisis. DNB (2011) reported that PFs were acting countercyclically by buying equities in falling markets during the global financial crisis. Before the crisis, in the time period 19992006, PFs also invested countercyclically by partly rebalancing their portfolios (Bikker et al., 2010). On average, about $39 \%$ of excess equity returns were rebalanced each quarter, leaving $61 \%$ of the portfolio for free float. The authors also highlight that PFs reacted asymmetrically to market shocks: rebalancing was much stronger after negative equity returns and large funds rebalanced their portfolios to a lesser extent than small funds. De Haan and Kakers (2011) confirm that Dutch PFs invested countercyclically before the crisis by applying rebalancing strategies, as they find a negative correlation between asset class returns and net investments in the asset class. In this paper, we expand these previous studies on the investment behaviour of PFs by focussing on whether market movements influenced their actual transactions. Moreover, we include ICs in our analysis.

Regarding ICs, Houben and van Voorden (2014) consider the equity sales and sovereign debt exposures of Dutch ICs. They show that when stock markets declined, Dutch ICs actively decreased their exposure to equity markets. Moreover, they also observe a flight to quality in the sovereign bond portfolio of Dutch ICs. This is in line with Bijlsma and Vermeulen (2015), who find that during the height of the European sovereign debt crisis ICs engaged in procyclical investment behaviour by selling southern European assets. While they investigate the country allocation decisions of ICs' sovereign bond portfolio during different phases of the crisis, we are interested in the influence of market movements on the equity and sovereign bond investment decisions made by both ICs and PFs.

\section{Equity and bond portfolio of Dutch ICPFs over time}

By analysing the transactions of Dutch ICPFs, we provide general insight into their investment behaviour during turbulent times. We use this insight to make a first assessment on whether their investment behaviour may have amplified market movements. Section 3.1 describes the data used for analysing the bond and equity portfolios. Section 3.2 highlights some key developments of the Dutch ICPF sector and their investments. Section 3.3 reveals the first results regarding the investment behaviour of ICPFs during the global financial crisis and European sovereign debt crisis.

\subsection{Dataset}

We use a unique institution-specific database for Dutch ICPFs over the period 2006Q1-2015Q1, covering both the global financial crisis and European sovereign debt crisis. ${ }^{3}$ The global financial crisis

\footnotetext{
${ }^{3}$ The underlying data are institution specific and therefore confidential. Hence, throughout the paper we show only
} 
is particularly relevant for analysing the equity portfolio and the sovereign debt crisis for the sovereign bond portfolio. Data is obtained from the balance of payments statistics, which contains detailed information on the holdings of assets, split by the country of origin and sector, at an institutional level. Moreover, it also contains information on the flow data, i.e. purchases and sales of assets. ICPFs also invest via investment funds. Due to limited data availability, we are only able to include the investments of ICPFs via investment funds from the end of 2008 onwards.

\subsection{Characteristics of investment portfolio of Dutch ICPFs}

Due to the compulsory participation in industry-wide PFs for companies, Dutch PFs manage large assets of about EUR 1,200 bln. This equals 190\% of Dutch GDP, EUR 74,400 per inhabitant, and 36\% of total PFs' assets in Europein 2013. ICs have fewer assets under management: around EUR 500 bln, or almost $80 \%$ of Dutch GDP, EUR 30,800 per habitant, and 5\% of total European ICs' assets.

Figures 1 and 2 show the asset allocation of Dutch ICPFs. Since the second half of 2009, PFs have been ramping up their investments in investment funds. Currently, investment funds manage more than half (57\%) of total PF assets. In 2006, this was only 20\%. The proportion total assets in investment funds for ICs is relatively stable at about $25 \%$ over our time horizon. Due to data availability we can only include investments via investment funds from 2008Q4 onwards. Figures 3 and 4 show the portfolios managed by investment funds on behalf of ICPFs ("look-through"). Even in these graphs, there is still a considerable amount classified as "investment funds." This is because investment funds also invest in other investment funds. For these investments, we are unable to apply the look-through approach and obtain a further breakdown. Throughout this paper, we will refer to investments performed by ICPFs directly as "direct investments" and to investments performed by investment funds on behalf of ICs and PFs as "indirect investments".

Figure 1: Direct asset allocation pension funds

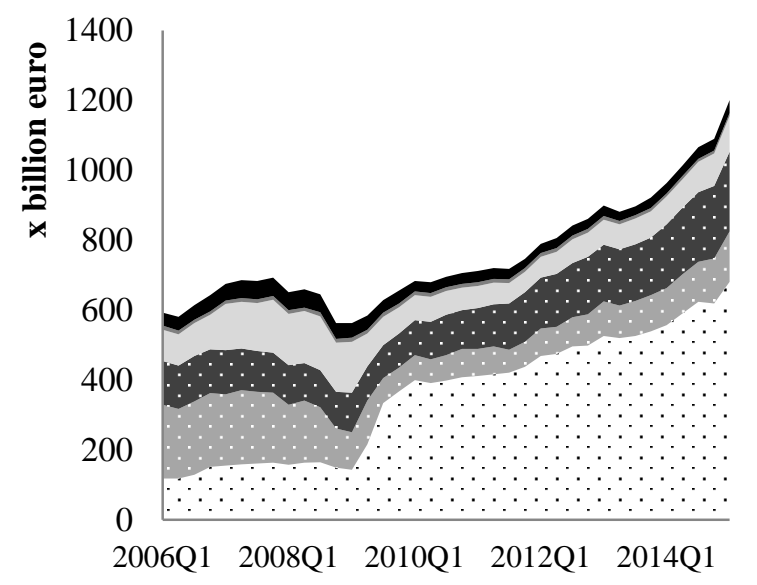

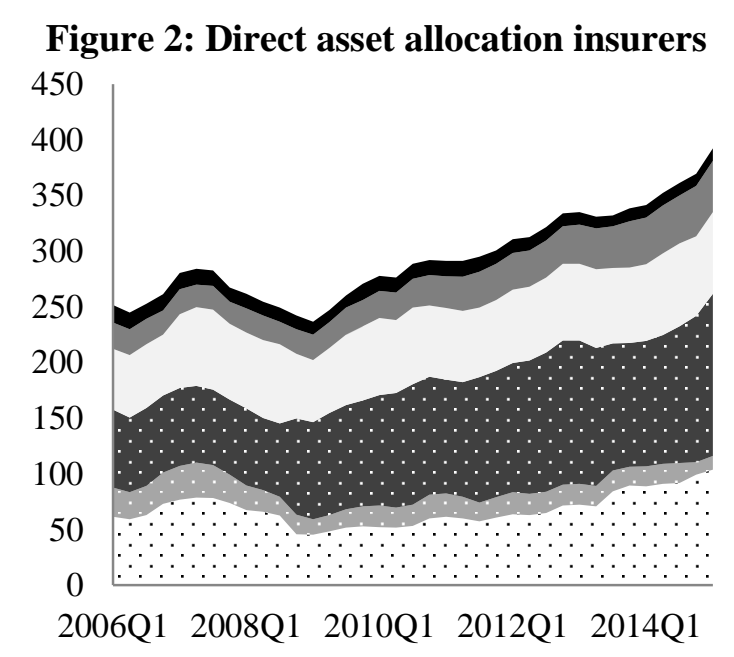

Government bonds

- Other

aggregated data or estimation results. 
Figure 3: Indirect asset allocation pension funds

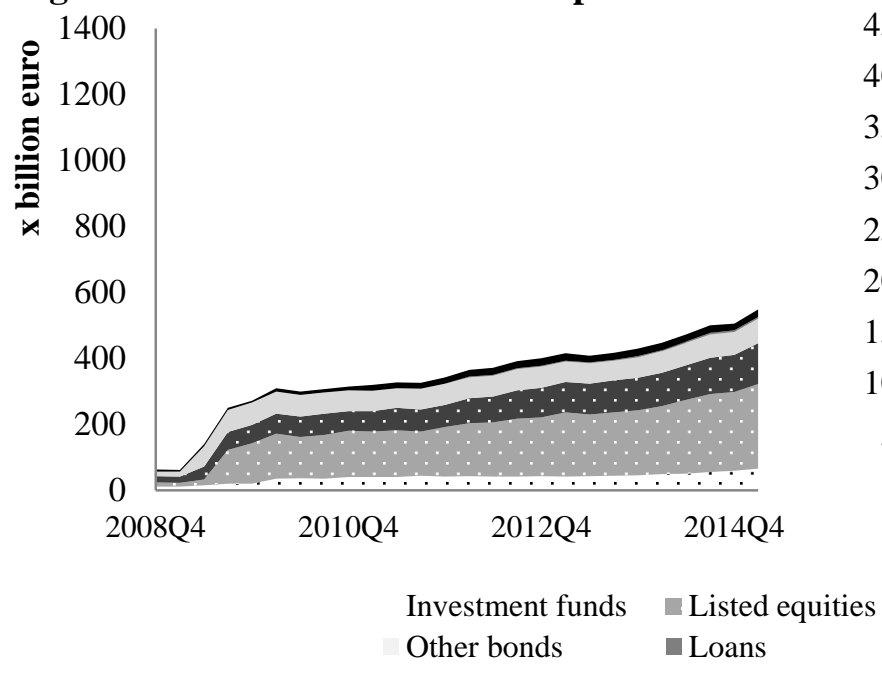

Figure 4: Indirect asset allocation insurers

450

400

350

300

250

200

150

100

50

0

2008Q4 2010Q4 2012Q4 2014Q4

Government bonds

- Other

Table 3: Development of two key investment portfolios

This table shows the shares in equities and sovereign bonds as a $\%$ of ICPFs' total investment portfolio.

\begin{tabular}{rrrrrr}
\hline & \multicolumn{2}{c}{ Equities } & \multicolumn{2}{c}{ Sovereign bonds } \\
& & $2008 \mathrm{Q} 4$ & $2015 \mathrm{Q} 1$ & $2008 \mathrm{Q} 4$ & $2015 \mathrm{Q} 1$ \\
\hline \multirow{3}{*}{ Total } & $\mathbf{2 3 \%}$ & $\mathbf{3 5 \%}$ & $\mathbf{2 2 \%}$ & $\mathbf{3 0 \%}$ \\
& Indirect & $19 \%$ & $47 \%$ & $30 \%$ & $23 \%$ \\
& Direct & $23 \%$ & $24 \%$ & $21 \%$ & $37 \%$ \\
& Total & $\mathbf{1 0 \%}$ & $\mathbf{7 \%}$ & $\mathbf{4 1 \%}$ & $\mathbf{4 5 \%}$ \\
\multirow{3}{*}{} & Indirect & $39 \%$ & $23 \%$ & $20 \%$ & $30 \%$ \\
& Direct & $8 \%$ & $4 \%$ & $42 \%$ & $47 \%$ \\
\hline
\end{tabular}

Dutch ICPFs invest most of their portfolio in equity and fixed income, although equity investments of ICs declined over the sample period, both in direct and indirect holdings (Figures 1-4). At 2008 year-end, ICs allocated around $10 \%$ to equities (Table 3). However, of their direct investments only $8 \%$ is invested in equity, while for the indirect investments $39 \%$ is in equity. By the beginning of 2015, this declined to $7 \%$ (4\% directly and 23\% indirectly). At the same time, PFs ramped up their (indirect) equity investments from 23\% in 2008 Q4 (23\% directly and 19\% indirectly) to 35\% in 2015Q1 ( $24 \%$ directly and $47 \%$ indirectly). Another noteworthy trend is that sovereign bond holdings have risen over the observed period, for both ICs and PFs. The total sovereign bond allocation of ICs and PFs rose from $22 \%$ and $41 \%$ in 2008 Q4 to respectively $30 \%$ and 45\% in 2015Q1. This also reflects valuation effects and likely increased supply. 


\subsubsection{Investment behaviour during the global financial and European sovereign debt crisis}

While aggregate information on the asset allocation of ICPFs is useful in its own right, it is not useful for analysing procyclicality, because it does not correct for valuation effects. In other words, a rise in equity allocation could be driven by both a positive sentiment on the stock market and/or an actual increase in the amount of shares. For analysing procyclicality, we obtain data on the net sales and purchases of equities and bonds, adjusted for valuation effects. In the following subsections, we compare these actual transactions conducted by ICPFs with market movements.

\subsubsection{Equity transactions versus market movements}

Figures 5 and 6 reveal that PFs behaved countercyclically and ICs procyclically right after the global financial crisis. While PFs started buying equities in falling markets, ICs reduced their equity holdings. PFs also sold a large chunk of their direct equity portfolio when markets hit all time lows in 2009, but overall, they bought EUR 1.2 bln of equities over the period 2007Q3 - 2009Q1. ICs, on the other hand, were net sellers of equity over the same period, selling in total EUR $6.7 \mathrm{bln}$ of their portfolio. While PFs invested contrary to market movements during the global financial crisis (the correlation coefficient between the stock market index and the 6-quarter moving of equity transactions is - 0.54 during 2007Q42010Q4), there is a strong comovement between ICs' equity transactions and the stock market index, as indicated by a correlation coefficient of 0.88 . For both ICs and PFs, the majority of instutions engaged in similar investment behaviour during the global financial crisis, i.e. over this period on average each quarter $50 \%$ of PFs and $62 \%$ of ICs were net sellers of equity. Results are therefore not biased by the transactions of a few large institutions. There could, however, be some over or underestimation due to missing data for indirect investments over the period 2006Q1 - 2008Q4: around 20\% and 25\% of the total allocation for PFs and ICs is missing from the data during this period. 


\section{Figure 5: Direct and indirect equity transactions by pension funds}

Figures 5 and 6 show the net equity transactions (buying/selling) by PFs over the period 2007Q3-2015Q1. The period 2007Q3-2008Q4 does not include indirect investments. The six quarter moving average of the relative equity transactions (defined as net equity transactions in period $t$ divided by the total equities held by the ICPF in period t-1) and the MSCI World Index are shown on the right-hand scale. In Figure 5, 2009 Q3 shows an outlier both for direct and indirect investments, of respectively EUR +74 and -75 bln. This is because of some PFs that transferred their equities to investment funds. Hence, it does not reflect a true sale of equities.

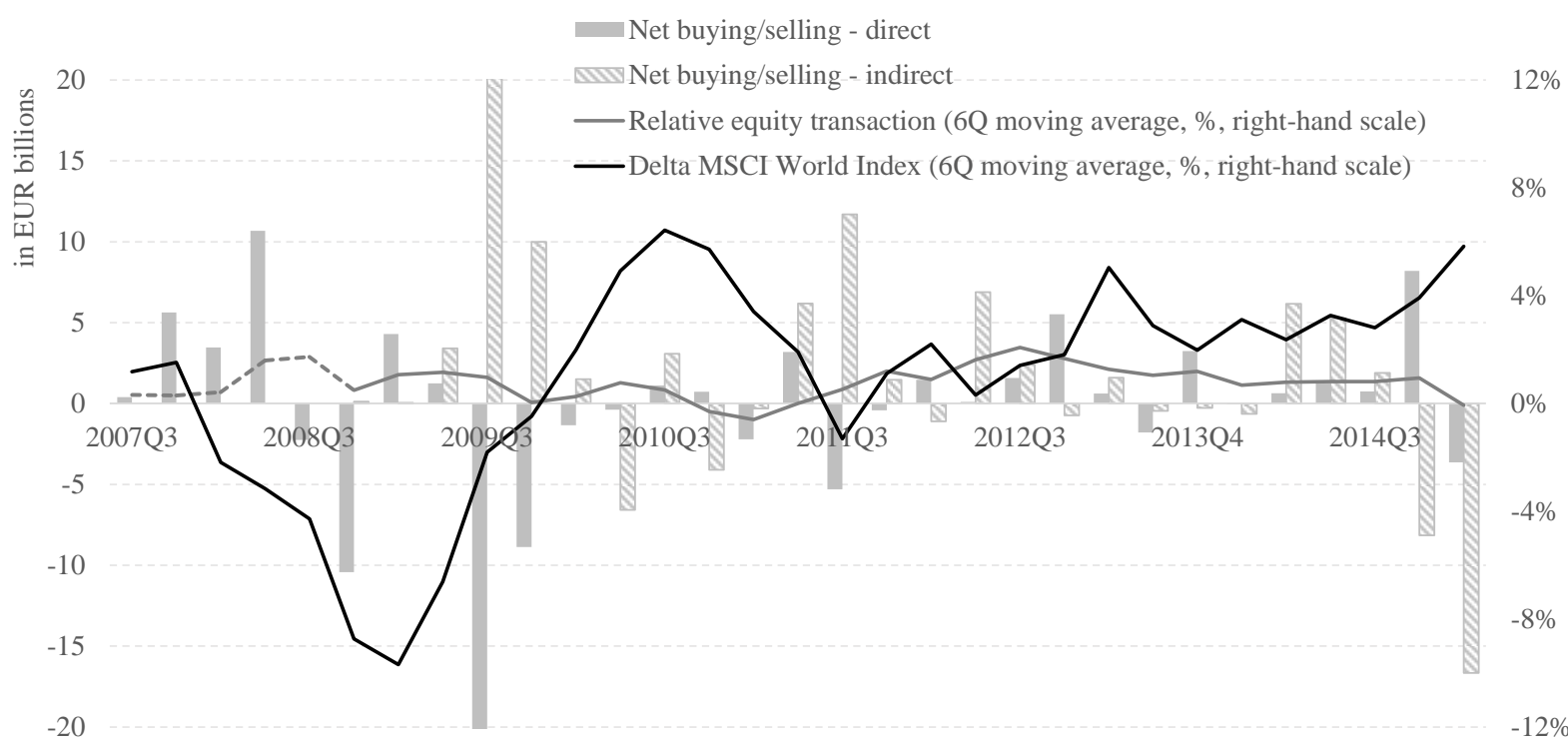

Figure 6: Direct and indirect equity transactions by insurers

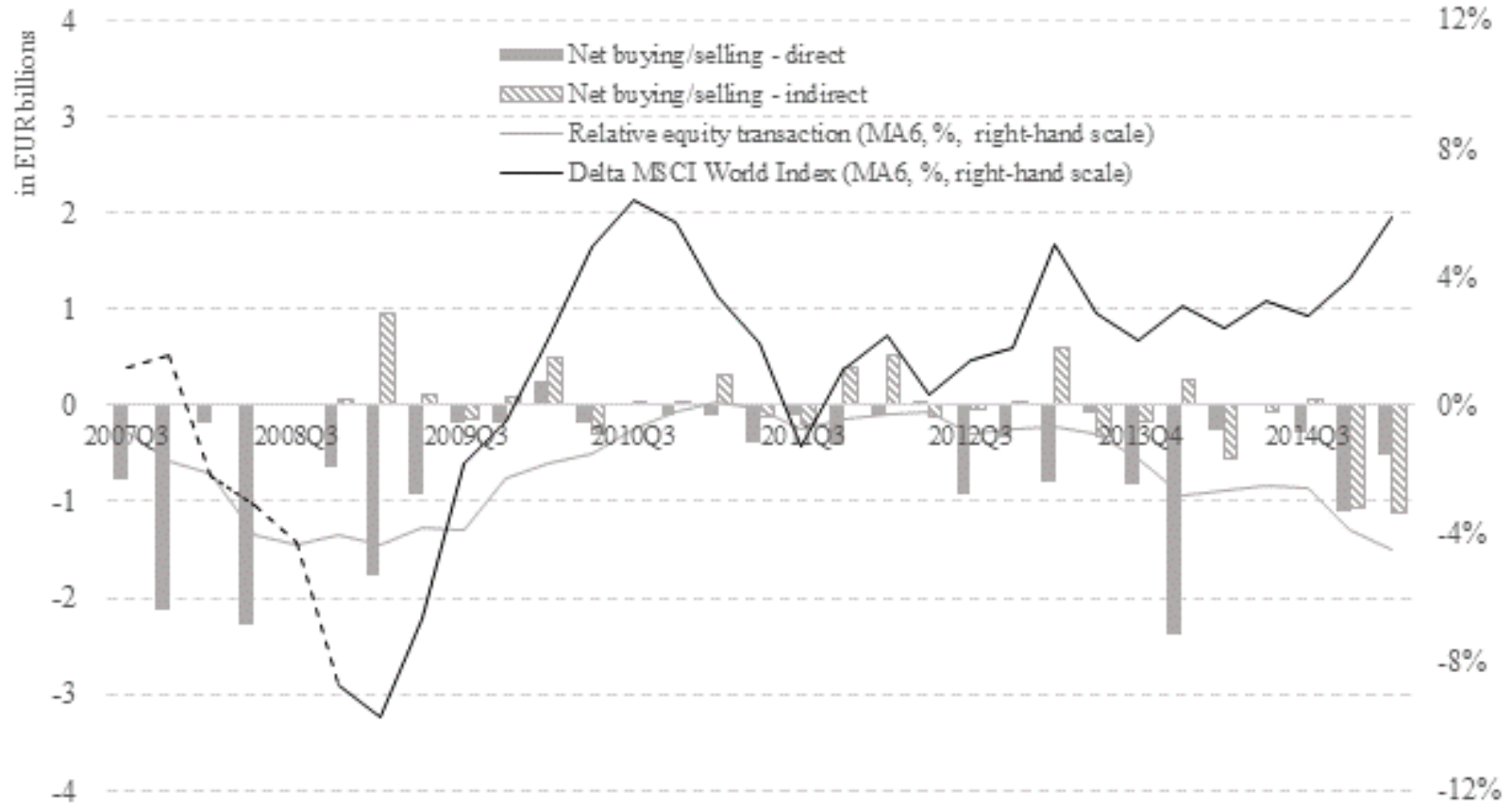

As markets bottomed out in 2010, ICs kept selling equities, albeit at a slower pace. Probably due to the foreseen implementation of new regulation and increased pressure on ICs' business models, ICs have engaged in a structural shift away from equities over the last couple of years. Therefore, it is hard to assess to what extent transactions are driven by market movements. Over the full observed period, there 
is no clear pattern between the asset allocation and the stock market index: the correlation for ICs is 0.24 - much lower than during the financial crisis. For PFs, this relationship also becomes weaker after the financial crisis (correlation of -0.28 compared to -0.54 during the crisis). The total (direct plus indirect) relative equity transactions of PFs remained relatively stable. The next section investigates whether these observed relationships between direct equity transactions and stock prices are statistically significant.

For PFs, we are also able to obtain supervisory data on the strategic and actual asset allocation from 2007Q1 until 2014Q4 (see Figure 7). This includes both direct and indirect investments. While this data includes valuation effects, it reveals strategic choices about their equity allocation and to what extent rebalancing is applied to stick to strategic targets. It shows that the weak performance of equities during the global financial crisis has induced PFs to lower their strategic equity allocation. Moreover, in 2009, actual equity allocation was much lower than the strategic allocation, indicating that PFs were not fully rebalacing their portfolios to strategic levels.

\section{Figure 7: Pension funds' strategic versus actual equity allocation}

This figure shows the strategic and actual equity allocation for Dutch PFs, in relation to changes in the stock market index for the period 2007Q1-2014Q4.

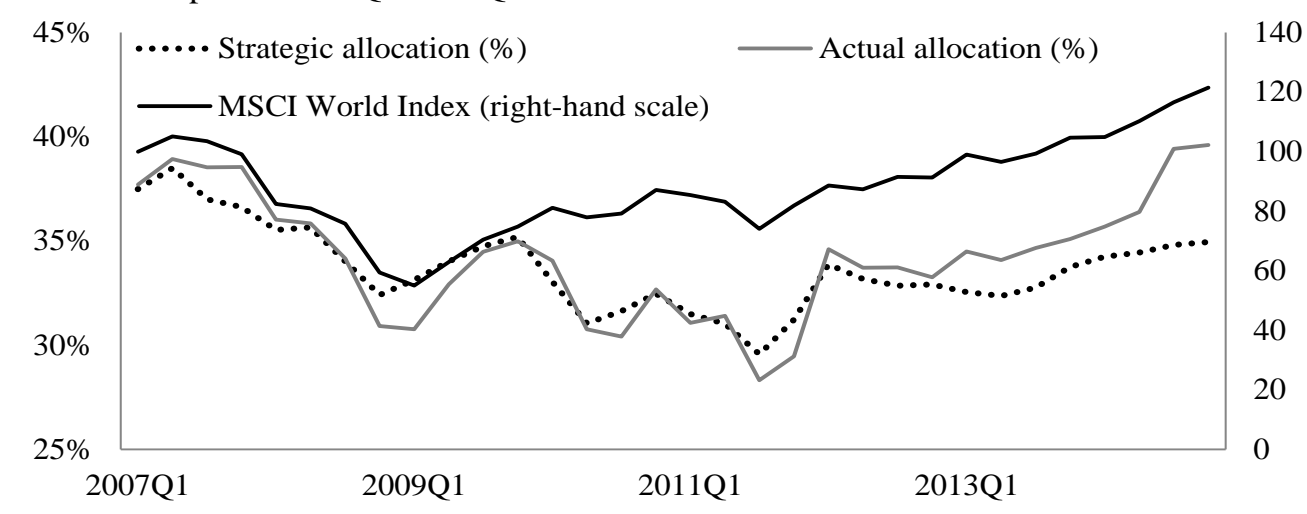

\subsubsection{Sovereign bond transactions versus downgrades}

Dutch ICPFs are important holders of European sovereign bonds. They allocate the largest part of their porfolios to Dutch, German and French bonds (Figures 8 and 9). After the outbreak of the European sovereign debt crisis, both sectors sold almost their entire direct exposure to the most affected countries - Greece, Ireland, Italy, Portugal and Spain (GIIPS) - even as their indirect holdings remained relatively constant. However, the allocation of sovereign bonds includes valutation effects. Figures 10 and 11 show the net sales and purchases of sovereign bonds of GIIPS countries by ICPFs, without valuation effects. Especially during 2009-2010 ICs sold off their GIIPS exposures. This period is also featured by downgrades of GIIPS' sovereign debt. Only after the European sovereign debt crisis did ICs start buying again. For PFs, the same conclusions can be drawn. 
Figure 8: Breakdown pension funds' sovereign bond portfolio by country

The left panel displays the sovereign bonds directly held by PFs and the right panel shows the sovereign bonds held by investment funds on behalf of PFs.
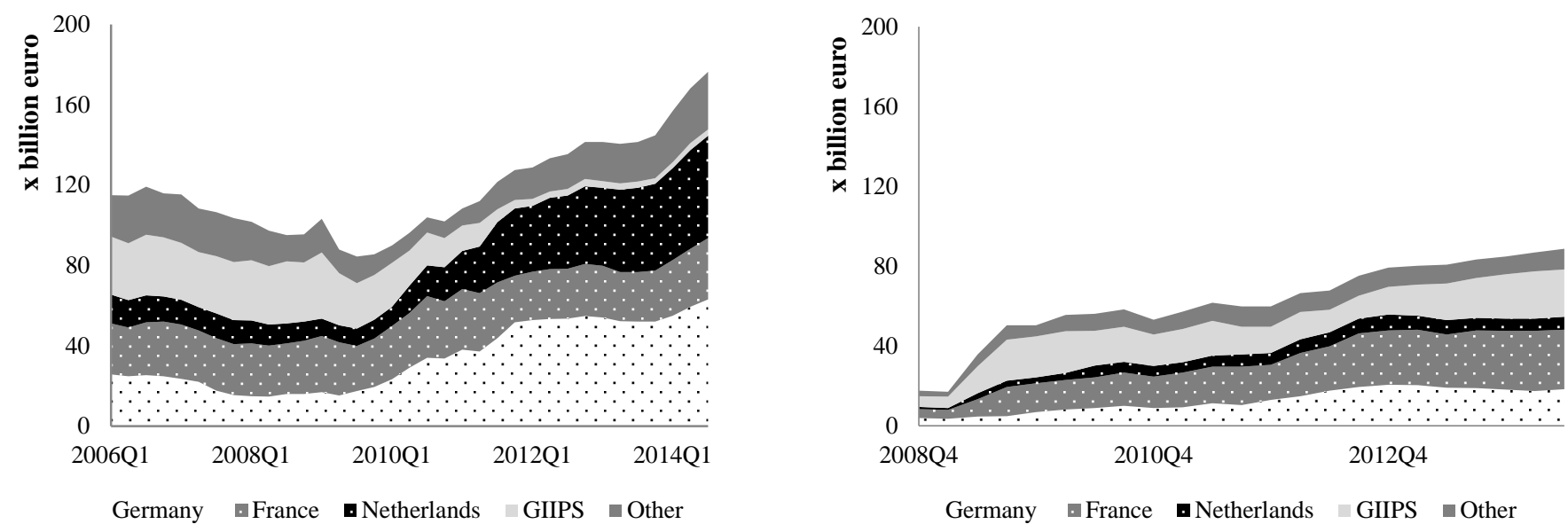

Figure 9: Breakdown insurance companies' sovereign bond portfolio by country

The left panel displays the sovereign bonds directly held by ICs and the right panel shows the sovereign bonds held by investment funds on behalf of ICs.
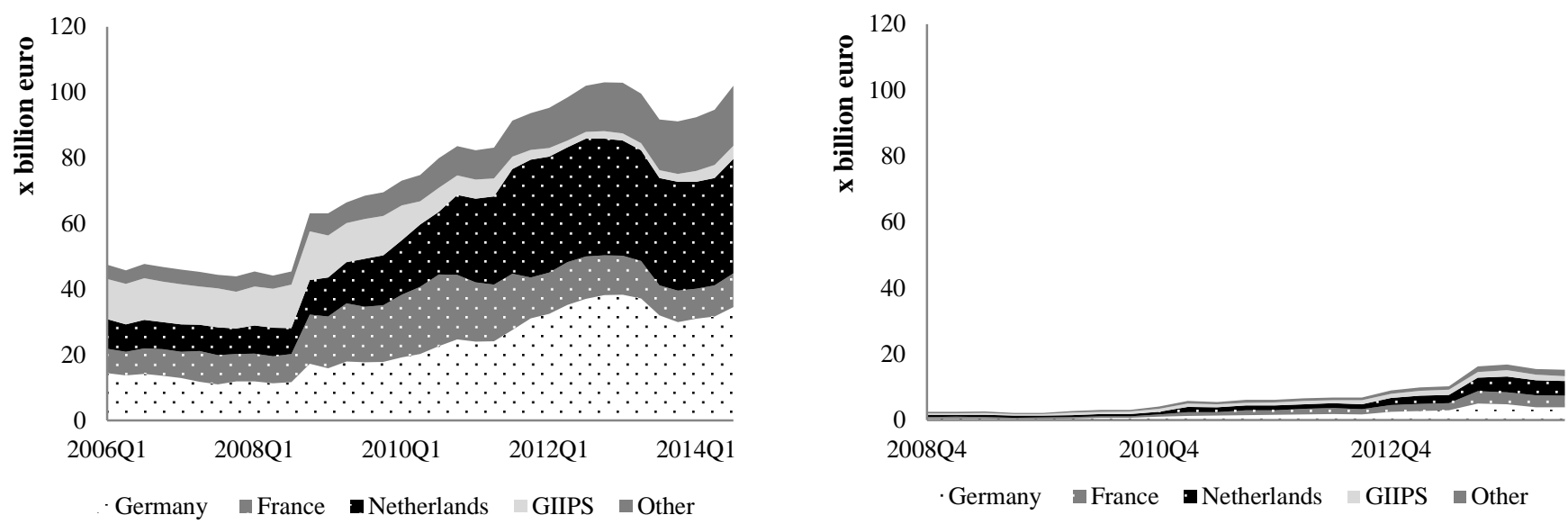


\section{Figure 10: Insurance companies' selling/buying of GIIPS exposures}

10 downgrades GIIPS

13 downgrades GIIPS

2 downgrades GIIPS

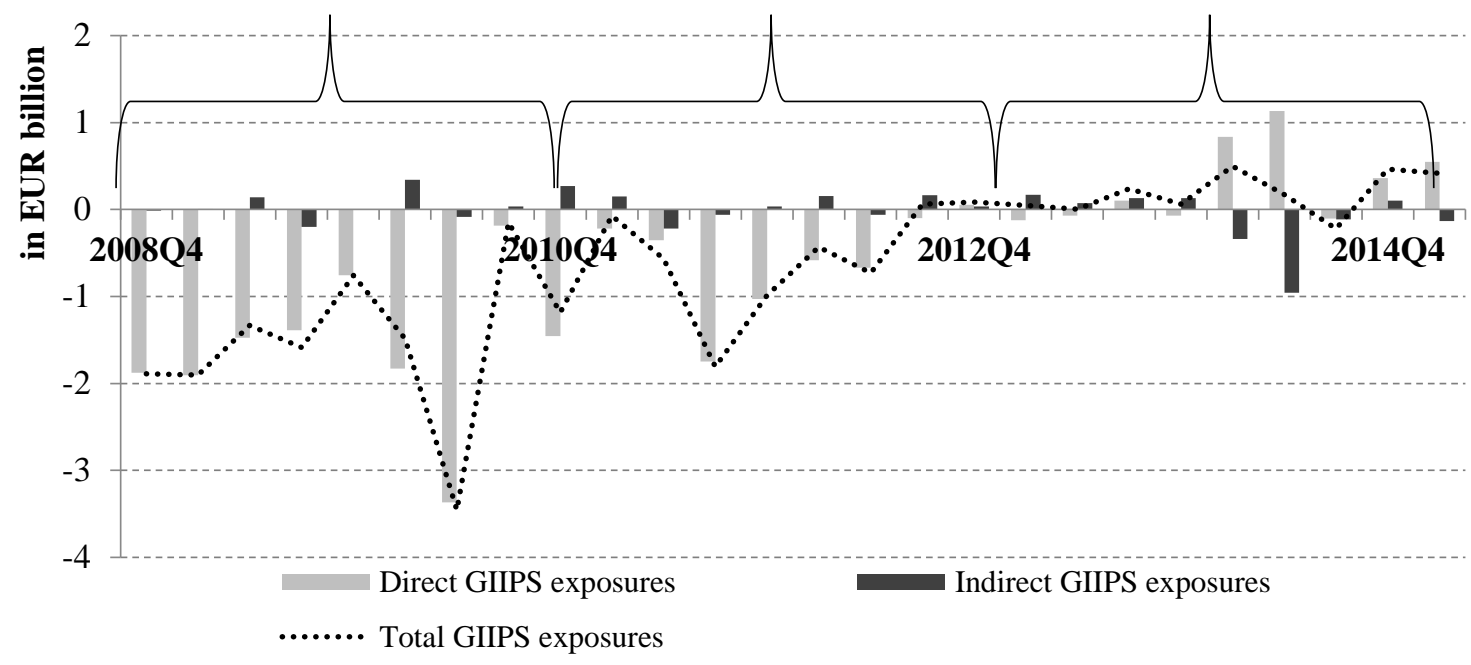

Figure 11: Pension funds' selling/buying of GIIPS exposures

2009Q2 and 2009Q4 show outliers both for direct and indirect investments, because some pension funds transferred their sovereign bonds to investment funds. Hence, it does not reflect a true sale of GIIPS exposures.

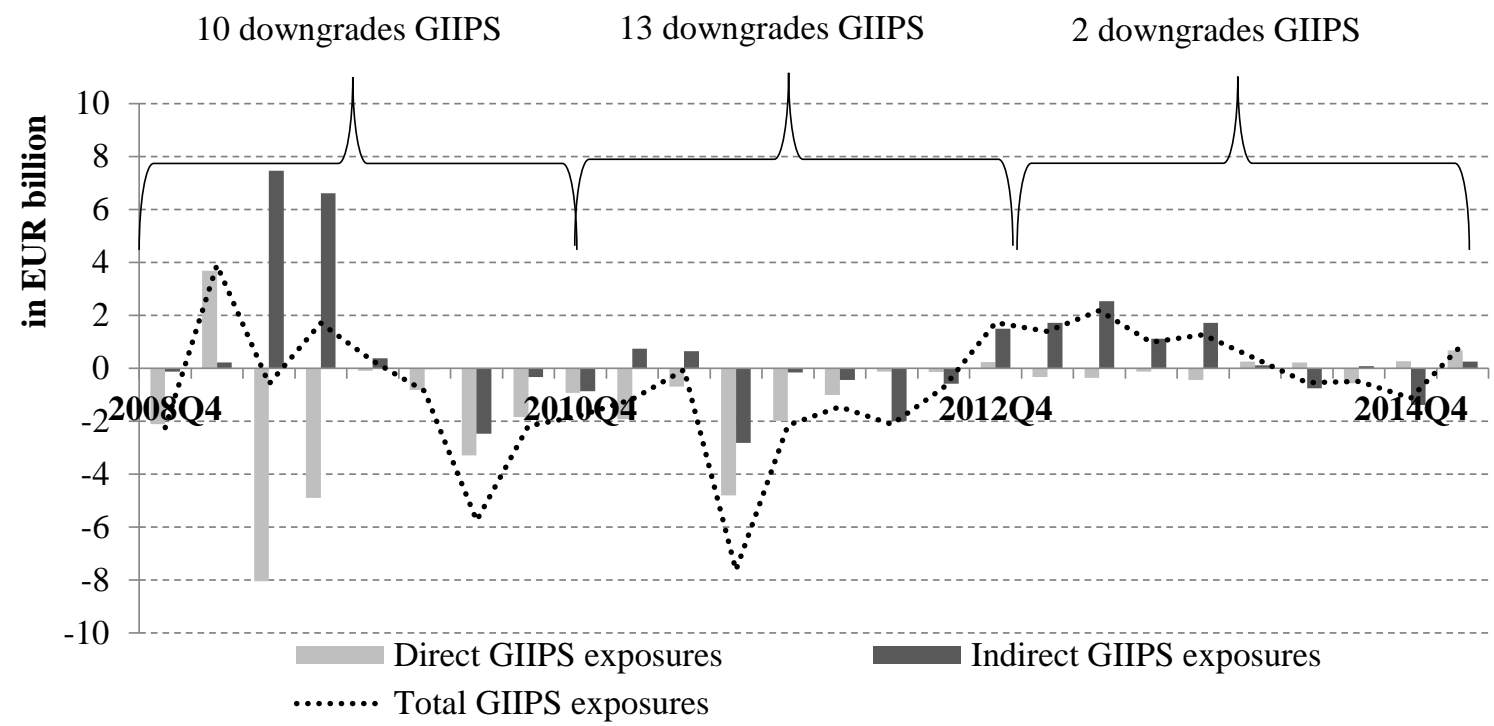

To assess whether the total sovereign bond allocation (direct plus indirect) has procyclical elements, we analyse response of ICPFs to sovereign rating downgrades. Only 15 countries for which ICPFs have an exposure of at least $1 \%$ of their total sovereign bond portfolio are included in the analysis, representing respectively $87 \%$ and $96 \%$ of the sovereign bond portfolio of PFs and ICs based on 2015Q1 data. ${ }^{4}$ We find that just before sovereign rating downgrades, ICPFs seem to have reduced their fixed income portfolios, selling around $10 \%$ of initial exposures in the preceding two quarters. After the

\footnotetext{
${ }^{4}$ These countries are Austria, Belgium, Finland, France, Germany, Greece, Ireland, Italy, Japan, the Netherlands, Portugal, Spain, Sweden, United Kingdom and United States.
} 
downgrade, their portfolio remained relatively stable. Figure 12 confirms this pattern: both ICs and PFs sold large parts of their sovereign bond portfolio in periods in which many countries were downgraded by rating agencies. At a macro level, this behaviour can be considered as destabilising, as it may have contributed to the deteriorating financing conditions of the affected countries. From an individual ICPF perspective, however, it could be rational to sell these bonds, especially when their rating is at the border of investment grade or when the assessed riskiness and fundamentals of a country structurally changed.

\section{Figure 12: ICPF's response to rating downgrades}

This figure shows ICPF's average response function to a rating downgrade. Time $t=0$ represents the quarter of the downgrade, while -2 (2) and -1 (1) respectively represent two quarters and one quarter before (after) the downgrade. The graph represents the net sales and purchases relative to the initial portfolio at $t=0$.

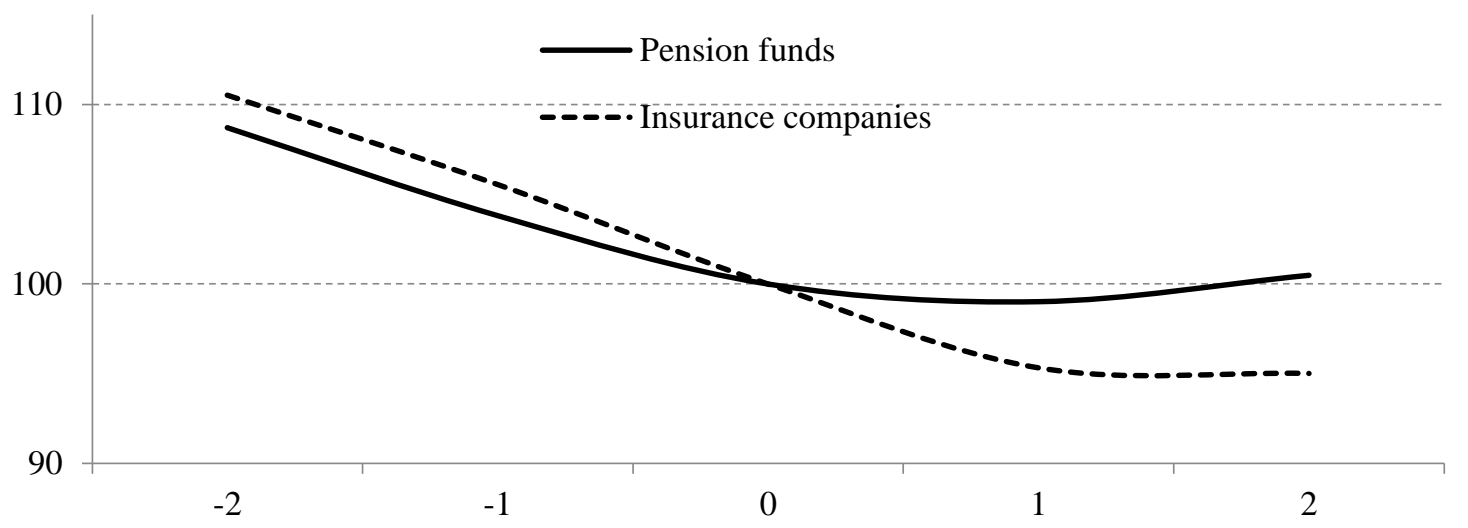

\section{Methodology and results of assessing equity investment behaviour}

This section reveals the approach, sources and results of the empirical research on the equity investments of Dutch ICPFs. Section 4.1 discusses the details of the sample, including summary statistics. Section 4.2 presents the methodology applied to test whether equity returns have significant power in explaining the equity selling/buying behaviour of ICPFs. Section 4.3 presents the results of the analysis.

\subsection{Data and descriptive statistics}

To empirically test whether Dutch ICPFs' equity transactions are triggered by market movements, we conduct a regression analysis on their relative equity transactions. We narrow down the original dataset to 17 ICs and 29 PFs, covering respectively $80 \%$ and $74 \%$ of both sectors. This sample set only contains ICPFs that report data over the full observed period. Data on asset allocation and transactions are obtained from the balance of payments statistics. Moreover, we collect supervisory data to control for institution specifics, such as size and solvency position. ${ }^{5}$ This supervisory data is available for the period 2006Q1-2014Q4. Table 4 provides descriptive statistics of our dataset.

\footnotetext{
${ }^{5}$ For insurance companies only yearly data is available for the years 2006-2008. Therefore, we interpolated this yearly data to construct quarterly data.
} 
The variable "relative equity transaction" is defined as the net equity transactions in period t divided by the total equities held by the ICPF in period t-1. Hence, it measures the amount of equities sold or bought expressed as a fraction of total equities in the portfolio. It does not say anything about the equity allocation, as it does not take into account the change in other assets in the portfolio. While PFs' equity allocation decreased over the last years, on average they sold about the same amount of equities as they bought (mean of relative transaction is 0 ). ICs, on the other hand, were net equity sellers during our sample period, as indicated by the negative mean and left-skewed distribution of relative equity transactions.

\section{Table 4: Descriptive statistics}

This table shows the descriptive statistics of our dataset of 17 ICs and 29 PFs. It includes the average, median and $10 \%$ - and $90 \%$ percentiles of the key variables used in our regression analysis.

\begin{tabular}{lccccc}
\hline Pension funds - variable & Mean & Median & $\mathbf{1 0 \%}$ & $\mathbf{9 0 \%}$ & St. Dev. \\
\hline Relative equity transactions (\%) & $0.0 \%$ & $0.5 \%$ & $-8.1 \%$ & $7.3 \%$ & $8.2 \%$ \\
Total assets (in $€$ million) & 20,793 & 6,645 & 2,066 & 34,752 & 46,765 \\
Equity allocation (\%) & $32 \%$ & $32 \%$ & $13 \%$ & $50 \%$ & $16 \%$ \\
Solvency ratio (\%) & $119 \%$ & $113 \%$ & $96 \%$ & $147 \%$ & $19 \%$ \\
Recovery period (\# of quarters) & 11.4 & 11.7 & 1.8 & 22.2 & 7.8 \\
\hline Insurance companies - variable & Mean & Median & $\mathbf{1 0 \%}$ & $\mathbf{9 0 \%}$ & St. Dev. \\
\hline Relative equity transactions (\%) & $-3.3 \%$ & $-0.7 \%$ & $-17.6 \%$ & $6.8 \%$ & $11.2 \%$ \\
Total assets (in $€$ million) & 18,458 & 4,300 & 1,526 & 52,869 & 23,139 \\
Equity allocation (\%) & $10 \%$ & $8 \%$ & $0.5 \%$ & $23 \%$ & $9 \%$ \\
Solvency ratio (\%) & $331 \%$ & $258 \%$ & $181 \%$ & $423 \%$ & $316 \%$ \\
\hline
\end{tabular}

The size of the institutions included in the sample, measured by total assets, varies strongly. The rightskewed distribution indicates the presence of some relatively large institutions. The equity allocation also varies strongly across ICPFs. Both IC and PFs report a quite high average solvency ratio, although these numbers also show substantial variance across institutions: average ICs' average solvency ratio is $331 \%$, based on the European Solvency I framework, and PFs' average coverage ratio equals 119\%. According to the Dutch regulatory framework for PFs, a ratio below 105\% requires PFs to prepare a recovery plan. In that case, PFs are not allowed to increase their risk profile, but they are also not forced to lower their risk profile. The variable "recovery period" shows the average number of quarters a PF is in a recovery phase.

Since we do not know what part of an investment fund's portfolio belongs to which specific institution (ICPF), we cannot add indirect to direct investments on an institution by institution basis. Therefore, one clear drawback of our dataset is that we are unable to include indirect equity investments in the regression. This is particularly problematic for PFs, as they have outsourced a large part of their portfolio to investment funds since 2009Q2. In some quarters we observe large "sales" of direct equity investments to investment funds, which are actually just transferred to an investment fund. We partially correct for this by excluding observations of relative equity transactions above $50 \%$ and below $-50 \%$. 


\subsection{Methodology}

In order to empirically test whether equity transactions are triggered by market movements, we apply five regression models. Each model has the same dependent variable: relative equity transactions, $\frac{T_{i, t}^{E}}{A_{i, t-1}^{E}}$, which measures the trading behaviour in equities by institution $i$ at time $t$, on a quarterly basis. To test whether these transactions are driven by market movements, we use three different specifications for equity returns as the key independent variable (see also Table 5):

i. The first two models use each ICPF's reported excess equity returns as the key independent variable. This variable measures the reported returns on equity investments relative to the reported returns on other assets in an ICPF's portfolio. This method is similar to Bikker et al. (2010). The excess equity return variable differs per ICPF as it depends on both the ICPF's portfolio allocation and the return on each security. However, there is a strong comovement among individual ICPFs' excess returns, because they are all influenced by similar market movements. In our first model, we do not include time fixed effects, since the Hausman test does not strongly reject random effects ${ }^{6}$, and more importantly, because we are particularly interested in the ICPF's response to common market shocks. In our second model, we do include fixed effects to test whether ICPFs' buying/selling decisions are influenced by small differences in ICPFs' returns, due to different asset allocations.

ii. In our third and fourth model, we replace the ICPF's self-reported reported returns with the ICPF's market excess equity returns for each asset class. These models do not take into account differences in returns within a certain asset class, thereby testing the robustness of the first two models. For each ICPF, the reported allocation to a certain asset class is multiplied by the market return of that asset class. We used the following market returns: MSCI World Index for the equity portfolio, the market prices of the main 15 government bond exposures, ${ }^{7}$ the JP Morgan Global Bond Index for the remaining part of the sovereign bond portfolio, the Barclays Global Corporate Bond Index for the corporate bond portfolio, the Dutch commercial property price index for the property exposures and the average interest rates on Dutch mortgages for the loan portfolio, as loans consist mainly of mortgages. Again, the third model does not and the fourth model does include time fixed effects.

iii. In our fifth model, the key independent variable is the return on the MSCI World Index, which is the same for all ICPFs. Our fifth model therefore assesses whether ICPFs react to common shocks in the equity market, regardless of their obtained returns and their portfolio allocation.

\footnotetext{
${ }^{6}$ The p-value equals 0.319 and 0.107 for pension funds and insurance companies respectively.

${ }^{7}$ For a list of the 15 countries analysed, see footnote 4 .
} 
Table 5: Regression model specifications

\begin{tabular}{llll}
\hline Model: & Dependent variable: & Price returns based on: & Time fixed effects: \\
\hline Model 1 & Reported excess equity return & ICPFs' reported return & No \\
Model 2 & Reported excess equity return & ICPFs' reported return & Yes \\
Model 3 & Market excess equity return & Market returns & No \\
Model 4 & Market excess equity return & Market returns & Yes \\
Model 5 & MSCI World Index & - & - \\
\hline
\end{tabular}

This results in the following main regression models for ICs (1a) and PFs (1b):

$\frac{T_{i, t}^{E}}{A_{i, t-1}^{E}}=\alpha_{i}+\beta *\left(r_{i, t-1}^{E}-r_{i, t-1}^{o}\right)+\gamma * \frac{T_{i, t-1}^{E}}{A_{i, t-2}^{E}}+\delta * \Delta$ Solvency $_{i, t-1}+\theta * \Delta L N\left(\right.$ size $\left._{i, t-1}\right)+\varepsilon_{i, t}$

$\frac{T_{i, t}^{E}}{A_{i, t-1}^{E}}=\alpha_{i}+\beta *\left(r_{i, t-1}^{E}-r_{i, t-1}^{o}\right)+\gamma * \frac{T_{i, t-1}^{E}}{A_{i, t-2}^{E}}+\delta * \Delta$ Solvency $_{i, t-1}+\theta * \Delta L N\left(\right.$ size $\left._{i, t-1}\right)+\vartheta * \operatorname{Recovery}_{i, t-1}+\varepsilon_{i, t}$

Models $1-4$ include the excess equity returns $\left(r_{i, t-1}^{E}-r_{i, t-1}^{o}\right)$ as an independent variable. In models 1 and 2 , the equity return $r_{i, t}^{E}$ is defined as the reported return on equities by institution $i$ in period $t$ divided by the institution's total equities in period t-1. The return on the other assets of institution's portfolio $r_{i, t}^{o}$ is defined as the weighted average return on the other most important asset categories:

$$
r_{i}^{o}=\frac{\sum_{c=0}^{n}\left(r_{i, c}^{S B} * A_{i, c}^{S B}\right)+\left(r_{i}^{C B} * A_{i}^{C B}\right)+\left(r_{i}^{P} * A_{i}^{P}\right)+\left(r_{i}^{L} * A_{i}^{L}\right)}{\sum_{j=S B, C B, P, L} A_{i, j}}
$$

where $r_{i, c}^{S B}$ and $A_{i, c}^{S B}$ represent the reported returns and the institution's total holdings of sovereign bonds, of country c, and $r_{i}^{C B}, A_{i}^{C B}, r_{i}^{P}, A_{i}^{P}, r_{i}^{L}, A_{i}^{L}$ are the returns and holdings of corporate bonds, property and loans (which mainly consists of mortgages). The denominator is the sum of the total exposure to equity, sovereign bonds, corporate bonds, property, and loans. These five asset classes represent on average $84.5 \%$ of the total assets of the ICPFs in our sample, and thus provide a good indication for total returns. In models 3-4, reported excess returns are replaced with market excess returns of each asset class, as previously described, and in model 5, the excessreturn is replaced with the MSCI World Index return.

Several control variables are included in all our regression models. An individual fixed effect is added to account for differences in ICPFs' characteristics. To control for serial correlation, we also include the lagged dependent variable, $\frac{T_{i, t-1}^{E}}{A_{i, t-2}^{E}}$. The natural logarithm of total assets $\left(\operatorname{LN}\left(\operatorname{size}_{i, t}\right)\right)$ controls for the tendency of larger funds with sophisticated risk management to allocate larger parts of their portfolio to riskier assets. The solvency position $\left(\right.$ Solvency $\left._{i, t}\right)$ is included because institutions with higher buffers have more means to withstand market shocks. For PFs, we incorporate a dummy variable Recover $y_{i, t}$ which equals one if a PF has a funding ratio below 105\%. We add a constant term to control for a potential trend in the dependent variable, which is particularly relevant for ICs given that they were net 
sellers of equities during our observation period. To ensure stationarity, we take a first difference of the variables solvency and size. ${ }^{8}$ Lastly, we lag all independent variables by one quarter.

\subsection{Results}

\subsubsection{Insurance companies}

Table 6 shows the results of all five models for ICs. The results of our first and third model indicate that ICs react procyclically to market sentiment by selling (buying) equities when equities underperform (outperform) other asset classes in the previous period. The excess return coefficient equals 0.172 in the first model and 0.237 in the third model and are both significant at the $1 \%$ level. This implies that when the return on equities is $1 \%$ lower (higher) than the return on other assets, ICs sell (buy) on average $0.172 \%$ or $0.237 \%$ of their equity portfolio, respectively. The coefficient of the lagged dependent variable is significant and positive, as expected. The control variables solvency and size are very small and not significant. Size and solvency effects might however be partially captured by the inclusion of individual fixed effects.

When controlling for time fixed effects, as in our second and fourth model, the coefficients for the excess return turn out to be insignificant. Hence, there is a common shock to which all ICs react, influencing their buying/selling behaviour. The fifth model therefore tests whether ICs react to a common market shock. It turns out that ICs strongly react to market sentiment: ICs sell (buy) on average $0.261 \%$ of their equity portfolio when the MSCI Index decreases (increases) by $1 \%$.

To conclude, we find evidence that ICs react procyclically by selling (buying) equities after negative (positive) equity returns. It turns out that they react to common market shocks, indicating that equity market movements may trigger herding behaviour. The variety in ICs' returns due to different asset allocations do not influence the equity investment behaviour. ICs' returns.

\footnotetext{
${ }^{8}$ An Augmented Dickey-Fuller (ADF) test shows that a unit root cannot be rejected for these two variables.
} 
Table 6: Equity investment model - Insurance companies

This table shows the regression coefficients obtained by the Ordinary Least Squares (OLS) results for 17 ICs over the period 2006Q1-2014Q4. Standard error terms are robust to heteroskedasticity by using White robust standard errors. ***, **, and * denote significance at the $1 \%, 5 \%$ and $10 \%$ significance levels.

\begin{tabular}{|c|c|c|c|c|c|}
\hline Key independent variable & $\begin{array}{r}\text { Spec } \\
\text { Reported }\end{array}$ & $\begin{array}{l}\text { on 1: } \\
\text { ss returns }\end{array}$ & $\begin{array}{r}\text { Speci } \\
\text { Market }\end{array}$ & $\begin{array}{l}\text { on } 2: \\
\text { return }\end{array}$ & $\begin{array}{c}\text { Specification 3: } \\
\text { MSCI }\end{array}$ \\
\hline Models & (1) & (2) & (3) & (4) & (5) \\
\hline Constant & $-0.032 * * *$ & $-0.031 * * *$ & $-0.027 * * *$ & 0.004 & $-0.035 * * *$ \\
\hline Reported excess return $(-1)$ & $0.172 * * *$ & 0.057 & & & \\
\hline Market excess return $(-1)$ & & & $0.237 * * *$ & 1.615 & \\
\hline MSCI return $(-1)$ & & & & & $0.261 * * *$ \\
\hline Relative equity transaction $(-1)$ & $0.190 * *$ & $0.204 * * *$ & $0.185 * *$ & $0.196 * *$ & $0.186 * *$ \\
\hline$\Delta$ Solvency $(-1)$ & 0.003 & -0.001 & -0.000 & -0.007 & -0.000 \\
\hline$\Delta \operatorname{Ln}(\operatorname{size}(-1))$ & 0.008 & -0.024 & -0.000 & -0.016 & -0.003 \\
\hline Recovery(-1) & & & & & \\
\hline \# Obs. & 333 & 333 & 333 & 333 & 333 \\
\hline $\mathrm{R}^{2}$ & $9.95 \%$ & $19.89 \%$ & $10.24 \%$ & $20.15 \%$ & $10.45 \%$ \\
\hline $\mathrm{R}^{2}$ adj. & $4.18 \%$ & $4.34 \%$ & $4.49 \%$ & $4.63 \%$ & $4.71 \%$ \\
\hline Time fixed effects & No & Yes & No & Yes & - \\
\hline
\end{tabular}

\subsubsection{Pension funds}

Table 7 shows the results of all five models for PFs. Contrary to ICs, equity performance has a small, insignificant, negative impact on equity transactions in all models. Moreover, only the lagged dependent variable has a significant positive coefficient. While the size and solvency effects might partially be captured by the inclusion of individual fixed effects, we do not find any significant result for the recovery variable. Hence, contrary to our expectations, PFs that are in a recovery period do not significantly behave differently by selling more equities. Based on these results, there is no clear indication for procyclical or countercyclical investment behaviour by PFs. This is not in line with earlier research by Bikker et al. (2010), who find some evidence for countercyclical equity investments before the global financial crisis. However, an important caveat is that our regression model only considers the direct investments performed by ICPFs. This is especially important for PFs as they currently outsource most of their investments to investment funds.

\section{Table 7: Equity investment model - Pension funds}

This table shows the regression coefficients obtained by the Ordinary Least Squares (OLS) results for 29 PFs over the period 2006Q1-2014Q4. Standard error terms are robust to heteroskedasticity by using White robust standard errors. ***, **, and $*$ denote significance at the $1 \%, 5 \%$ and $10 \%$ significance levels.

\begin{tabular}{l|cc|cc|c}
\hline Key independent variable & \multicolumn{2}{|c|}{$\begin{array}{c}\text { Specification 1: } \\
\text { Reported excess returns }\end{array}$} & \multicolumn{2}{|c|}{$\begin{array}{c}\text { Specification 2: } \\
\text { Market excess return }\end{array}$} & $\begin{array}{c}\text { Specification 3: } \\
\text { MSCI }\end{array}$ \\
\hline Models & $\mathbf{( 1 )}$ & $\mathbf{( 2 )}$ & $\mathbf{( 3 )}$ & $\mathbf{( 4 )}$ & -0.002 \\
\hline Constant & -0.002 & -0.001 & -0.003 & -0.002 & \\
Reported excess return (-1) & -0.023 & -0.040 & & \\
Market excess return (-1) & & & -0.037 & -0.065 & -0.047 \\
MSCI return (-1) & & & & $0.091^{* *}$ \\
Relative equity transaction & $0.088^{* *}$ & $0.099 * *$ & $0.089 * *$ & $0.101^{* *}$ & \\
(-1) & & & & \\
$\Delta$ Solvency (-1) & 0.048 & -0.022 & 0.051 & -0.023 & 0.056 \\
$\Delta$ Ln(size(-1)) & 0.014 & 0.068 & 0.029 & 0.068 & 0.031
\end{tabular}




\begin{tabular}{l|cc|cc|c} 
Recovery(-1) & 0.008 & -0.003 & 0.008 & -0.003 & 0.008 \\
\# Obs. & 940 & 940 & 940 & 940 & 940 \\
$\mathrm{R}^{2}$ & $4.51 \%$ & $11.69 \%$ & $4.54 \%$ & $11.67 \%$ & $4.70 \%$ \\
$\mathrm{R}^{2}$ adj. & $1.02 \%$ & $4.91 \%$ & $1.06 \%$ & $4.87 \%$ & $1.25 \%$ \\
Time fixed effects & No & Yes & No & Yes & - \\
\hline
\end{tabular}

\subsubsection{Asymmetric model for ICs}

Institutions may react differently during periods of stress. A drawback of our model is that it is symmetric; it does not distinguish between equity outperformance and underperformance. Therefore, we extend our fifth model to assess whether institutions react asymmetrically to market shocks. First, we include two dummy variables to split equity returns into positive and negative observations. Second, we include dummy variables for crisis and non-crisis periods in order to check if there is a stronger relationship between equity investments and performance during the global financial crisis (2007Q32009Q2).

Table 8 shows the outcomes of this asymmetric model only for ICs, as also for the asymmetric model, the results are not significant for PFs. The coefficients in the left column reveal that ICs react more strongly to negative excess returns, i.e. when equities underperform relative to other asset classes. Both dummy coefficients are positive, but only the coefficient of the negative equity return variable is statistically significant. The results in the second column show that ICs showed stronger procyclical behaviour during the recent global financial crisis: the coefficient of the crisis dummy in the right column is higher and more statistically significant than the coefficient of the dummy for relatively tranquil periods. We tested for equality of the coefficients. However, differences between the coefficients of positive and negative MSCI returns are not statistically significant. The same holds for the differences between the coefficients of crisis and non-crisis interaction dummies.

Table 8: Asymmetric equity investments models - Insurance companies

This table shows the regression coefficients obtained by the Ordinary Least Squares (OLS) results for 17 ICs over the period 2006Q1-2014Q4. The heteroskedasticy of the error terms is reduced by using White robust standard errors. $* * *, * *$, and $*$ denote significance at the $1 \%, 5 \%$ and $10 \%$ significance levels.

\begin{tabular}{lcc}
\hline & Performance dummies & Crisis dummies \\
\hline Constant & $-0.033^{* * *}$ & $-0.031^{* * * *}$ \\
Positive MSCI return (-1) & 0.221 & \\
Negative MSCI return (-1) & $0.295^{* *}$ & \\
MSCI return(-1)*No crisis(-1) & & $0.183^{*}$ \\
MSCI return(-1)*Crisis(-1) & $0.185^{* *}$ & $0.373^{* * *}$ \\
Relative equity transaction(-1) & 0.000 & $0.181 * *$ \\
Solvency (-1) & -0.002 & 0.001 \\
Ln(size(-1)) & 333 & -0.005 \\
$\#$ Obs. & $10.47 \%$ & 333 \\
$\mathrm{R}^{2}$ & $4.43 \%$ & $10.70 \%$ \\
$\mathrm{R}^{2}$ adj. & & $4.67 \%$ \\
\hline
\end{tabular}




\section{Conclusion and policy implications}

With large amounts of assets under management, ICPFs can either amplify or stabilise market movements. This may have implications for the broader financial system and economy, as ICPFs are important providers of long-term financing to governments, companies and financial institutions. Our graphical assessment of the investment behaviour of Dutch ICPFs reveals that ICs invested procyclically and PFs somewhat countercyclically during the financial crisis, as PFs were net buyers (EUR 1.2 bln) and ICs net sellers (EUR 6.7 bln) of equity. Moreover, both ICs and PFs anticipate rating downgrades by selling the affected sovereign bonds prior to a downgrade.

Regression analyses over a longer time horizon confirm procyclical investment behaviour by ICs. For PFs, we do not find statistical evidence for procyclical or countercyclical behaviour. One important limitation of our regression analysis is that we are unable to include indirect investments. This particularly impedes our analyses of PFs, as they currently allocate most of their (equity) portfolio to investment funds. A possible reason for the different findings for ICs and PFs is that ICs may face more pressure on their business model in market downturns. While ICs could go bankrupt, PFs have more recovery options, for example by reducing policyholders' benefits. Moreover, and contrary to our expectations, we find that ICPFs' investment behaviour is not influenced by their solvency position. This suggests that regulatory pressure did not induce their buying and selling decisions.

Procyclical investment behaviour could be harmful for the stability of the financial system, meaning that there could be a role for policy. Since the global financial crisis, policy measures are even more focussed on improving the resilience of the overall financial system instead of single insitutions. This holds particularly for the banking sector, for which a macroprudential framework has been established. Expanding this framework beyond the banking sector is currently an important topic on the agenda of international policy makers.

In this context, policy makers may also want to focus on discouraging procyclical investments by large institutional investors. In doing so, there has to be a well-balanced trade-off between macro and microprudential objectives. From a macro perspective, for example, the system benefits from regulatory flexibility in times of stress, since it enables countercyclical investment behaviour. However, this may not desirable from a micro perspective, particularly not if institutions are coping with solvency problems. For some elements of regulation, the macro micro trade-off is easier to make than for others. While mark-to-market valuation forces institutions to be more concerned with short-term market movements, it is an important condition for proper risk management. Therefore, the alternative of having no markto-market valuation could be worse.

One measure that is desirable from both a macro and micro perspective is the building up of buffers during good times to withstand shocks during bad times. This measure has already been implemented for the banking sector (countercyclical buffer), and could be extended to other sectors. The new regulatory regime for ICs (Solvency II) already contains the volatility adjustment measure that lowers the buffer requirement for ICs in volatile times. However, it does not require ICs to build up 
buffers in good times. High solvency levels increase an institution's capacity to act as shock absorbers in times of stress. Therefore, this could be an interesting topic to explore further in current policy discussions on improving the resilience of both institutions and the overall financial system. 


\section{References}

Bank of England and Procyclicality Working Group (2014). Procyclicality and structural trends in investment allocation by insurance companies and pension funds.

Beber, A., Brandt, M. W., and Kavajecz, K. A. (2009). Flight-to-quality or flight-to-liquidity? Evidence from the euro-area bond market. Review of Financial Studies, 22(3), 925-957.

Bijlsma, M., and Vermeulen, R. (2015). Insurance companies' trading behaviour during the European sovereign debt crisis: Flight home or flight to quality? DNB Working Paper, no. 468.

Bikker, J. A., Broeders, D. W. G. A., and De Dreu, J. (2010). Stock market performance and pension fund investment policy: rebalancing, free float, or market timing. International Journal of Central Banking, 6(2), 53-79.

Blake, D., Lehmann, B. N., and Timmermann, A. (1999). Asset allocation dynamics and pension fund performance. The Journal of Business, 72(4), 429-461.

Blake, D., Sarno, L., and Zinna, G., The market for lemmings: the investment behaviour of pension funds. (2015). The Pensions Institute, Discussion paper, PI-1408

Borio, C., Furfine, C., and Lowe, P. (2001). Procyclicality of the financial system and financial stability: issues and policy options. BIS Working papers, 1, 1-57.

Brinson, G. P., Singer, B. D., and Beebower, G. L. (1991). Determinants of portfolio performance II: An update. Financial Analysts Journal, 47(3), 40-48.

Claessens, S., and Kose, M. M. A. (2013). Financial crises explanations, types, and implications. IMF Working Paper, no. 13-28.

Daniel, K., Hirshleifer, D., and Subrahmanyam, A. (1998). Investor psychology and security market under-and overreactions. Journal of Finance, 53(6), 1839-1885.

De Haan, L. and , Kakes, J., (2011). Momentum or contrarian investment strategies: Evidence from Dutch institutional investors. Journal of Banking \& Finance, 35(9), 2245-2251

De Nederlandsche Bank. (2011). Pensioenfondsen kochten per saldo aandelen bij. DNBulletin, 7 april. http://www.dnb.nl/nieuws/nieuwsoverzicht-en-archief/dnbulletin-2011/dnb250677.jsp

Domanski, D., Shin, H. S., and Sushko, V. (2015). The hunt for duration: not waving but drowning? BIS Working Paper, no. 519.

Haldane, A.G. (2014). The age of asset management? Speech given at the London Business School, London, April 14.

Houben, A.C.F.J. and van Voorden, J.P. (2014). Insuring the financial system aganst insurers: A macroprudential framework. In J. Monkiewicz and M. Malecki (eds.). Macroprudential Supervision in Insurance - Theoretical and Practical Aspects, Palgrave Macmillan, UK, pp. 66-84.

Impávido, G., Tower (2009), How the financial crisis affects pensions and insurances and why the impacts matter. IMF Working Paper, no. 09-151, Washington DC.

Joint FSF-CGFS Working Group. (2009). The role of valuation and leverage in procyclicality. CGFS papers, no. 34.

Keynes, John M., (1936). The general theory of employment, interest and money. New York, Harcourt, Brace and Company.

Papaioannou, M.G., Park, J., Pihlman, J., and Van der Hoorn, H. (2013). Procyclical behaviour of institutional investors during the recent financial crisis: causes, impacts, and challenges. IMF Working Paper, no. 13-193.

Rajan, R. G. (2005). Has financial development made the world riskier? NBER Working Paper No. 11728.

Rudolph, M. J. (2011). U.S. Insurance company investment strategies in an economic downturn. White Paper sponsored by Committee on Financial Research, Society of Actuaries (Schaumburg).

Scharfstein, D. S., and Stein, J. C. (1990). Herd behaviour and investment. The American Economic Review, 465-479. 
No. 454 Mauro Mastrogiacomo and Rob Alessie, Where are the retirement savings of self-employed? An analysis of 'unconventional' retirement accounts

No. 455 Clemens Bonner and Paul Hilbers, Global liquidity regulation - Why did it take so long?

No. 456 Leo de Haan, Jan Willem van den End and Philip Vermeulen, Lenders on the storm of wholesale funding shocks: Saved by the central bank?

No. 457 Wilko Bolt and David Humphrey, Assessing bank competition for consumer loans

No. $45^{8}$ Robert Beyer and Michael Stemmer, From progress to nightmare - European regional unemployment over time

No. 459 Stijn Claessens and Neeltje van Horen, The impact of the global financial crisis on banking globalization

No. 460 Francisco Blasques, Falk Bräuning and Iman van Lelyveld, A dynamic network model of the unsecured interbank lending market

No. 46I Carin van der Cruijsen, Lola Hernandez and Nicole Jonker, In love with the debit card but still married to cash

No. 462 Koen van der Veer, Loss shocks and the quantity and price of private export credit insurance: Evidence from a global insurer

No. 463 Cenkhan Sahin and Jakob de Haan, Market reactions to the ECB's Comprehensive Assessment

No. 464 Melanie de Waal, Floor Rink and Janka Stoker, How internal and external supervisors influence employees' self-serving decisions

No. 465 Andrea Colciago and Lorenza Rossi, Firms entry, oligopolistic competition and labor market dynamics

No. 466 Peter Heemeijer and Ronald Heijmans, Central bank intervention in large value payment systems: An experimental approach

No. 467 Natalya Martynova, Effect of bank capital requirements on economic growth: a survey

No. 468 Melle Bijlsma and Robert Vermeulen, Insurance companies' trading behaviour during the European sovereign debt crisis: Flight home or flight to quality?

No. 469 Robert Vermeulen, Marco Hoeberichts, Bořek Vašíček, Diana Žigraiová, Kateřina Šmídková and Jakob de Haan, Financial stress indices and financial crises

No. 470 Nicole Jonker, Mirjam Plooij and Johan Verburg, Does a public campaign influence debit card usage? Evidence from the Netherlands

No. 47I Carin van der Cruijsen en Mirjam Plooij, Changing payment patterns at point-of-sale: their drivers

No. 472 Christina Strobach and Carin van der Cruijsen, The formation of European inflation expectations: One learning rule does not fit all

No. 473 Jan Willem van den End and Christiaan Pattipeilohy, Central bank balance sheet policies and inflation expectations

No. 474 Dirk Broeders, Arco van Oord and David Rijsbergen, Scale economies in pension fund investments: A dissection of investment costs across asset classes

No. 475 Richhild Moessner, David-Jan Jansen and Jakob de Haan, Communication about future policy rates in theory and practice: A Survey

No. 476 Bořek Vašíček, Diana Žigraiová, Marco Hoeberichts, Robert Vermeulen, Kateřina Šmídková and Jakob de Haan, Leading indicators of financial stress: New evidence

No. 477 Rasmus Wiese, Richard Jong-A-Pin and Jakob de Haan, Are expenditure cuts the only effective way to achieve successful fiscal adjustment?

No. 478 Maarten van Oordt and Chen Zhou, Systemic risk of European banks: Regulators and markets

No. 479 Jon Frost, A theory of bazookas, or; "when (and when not) to use large-scale official sector support"

No. 480 Natalya Martynova and Enrico Perotti, Convertible bonds and bank risk-taking

No. 48I Dorinth van Dijk and Marc Francke, Internet search behavior, liquidity and prices in the housing market

No. 482 Simas Kucinskas, Liquidity creation without banks

No. 483 Reinder Haitsma, Deren Unalmis and Jakob de Haan, The impact of the ECB's conventional and unconventional monetary policies on stock markets

No. 484 Damiaan Chen, Roel Beetsma and Dirk Broeders, Stability of participation in collective pension schemes: An option pricing approach

No. 485 Leo de Haan, Recovery measures of underfunded pension funds: higher contributions, no indexation, or pension cuts? 
Previous DNB Working Papers in 2015 (continued)

No. 486 Alex van de Minne and Federica Teppa, Demand and supply of mortgage credit

No. 487 Yakov Ben-Haim and Maria Demertzis, Decision making in times of uncertainty: An info-gap perspective

No. 488 Irene Mostert, Dennis Veltrop, Paula van Veen-Dirks and Jakob de Haan, Pawn or Vigilant Watchdog? How board vigilance and board tenure moderate the effects of executive tenure on board functioning 

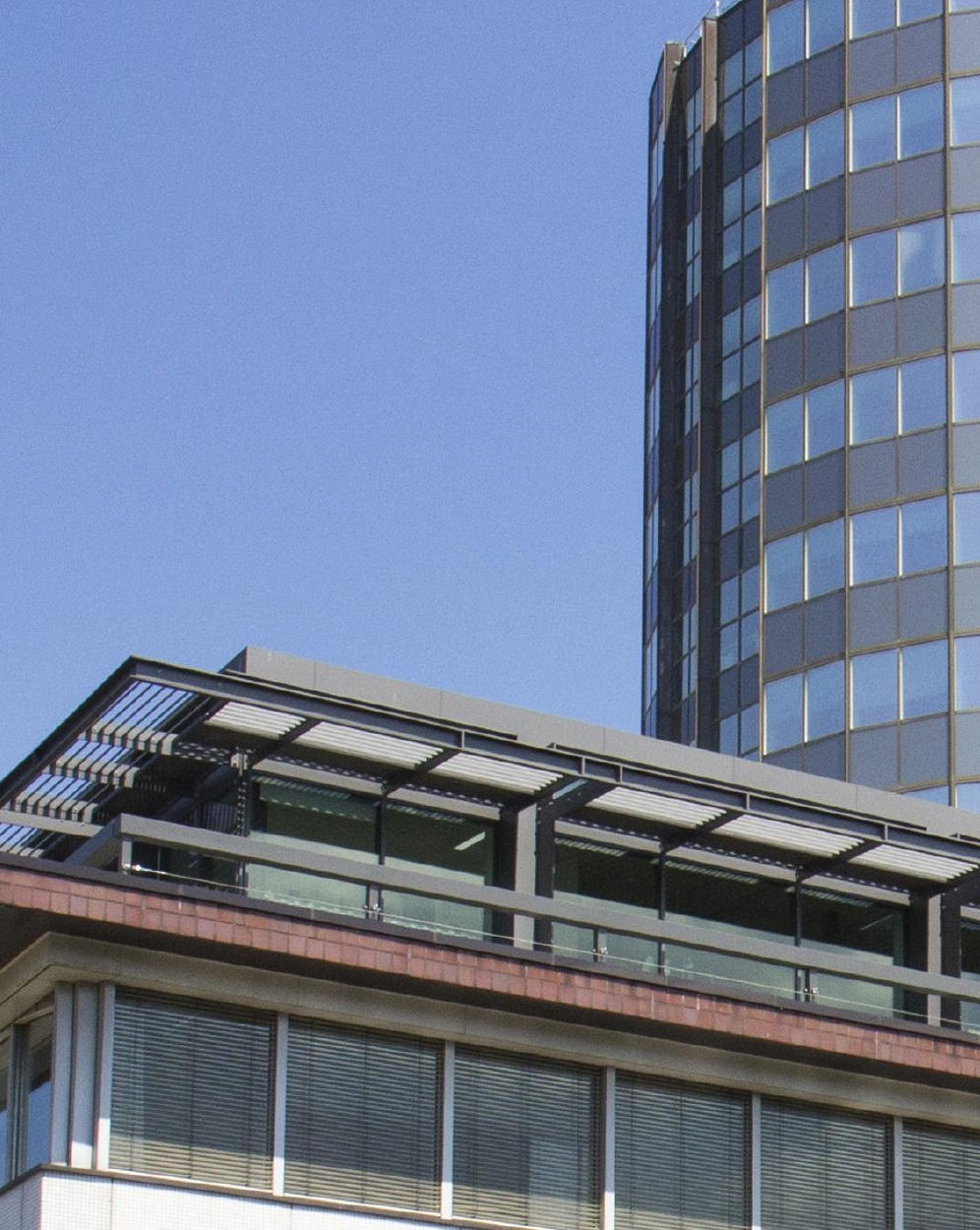

scis

111

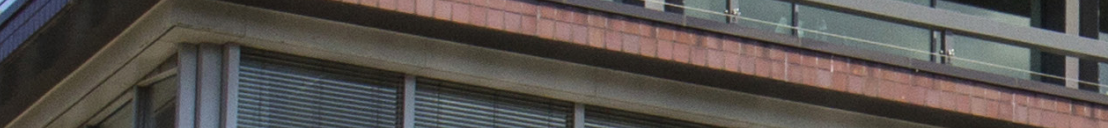

I. $\mathrm{a}$.
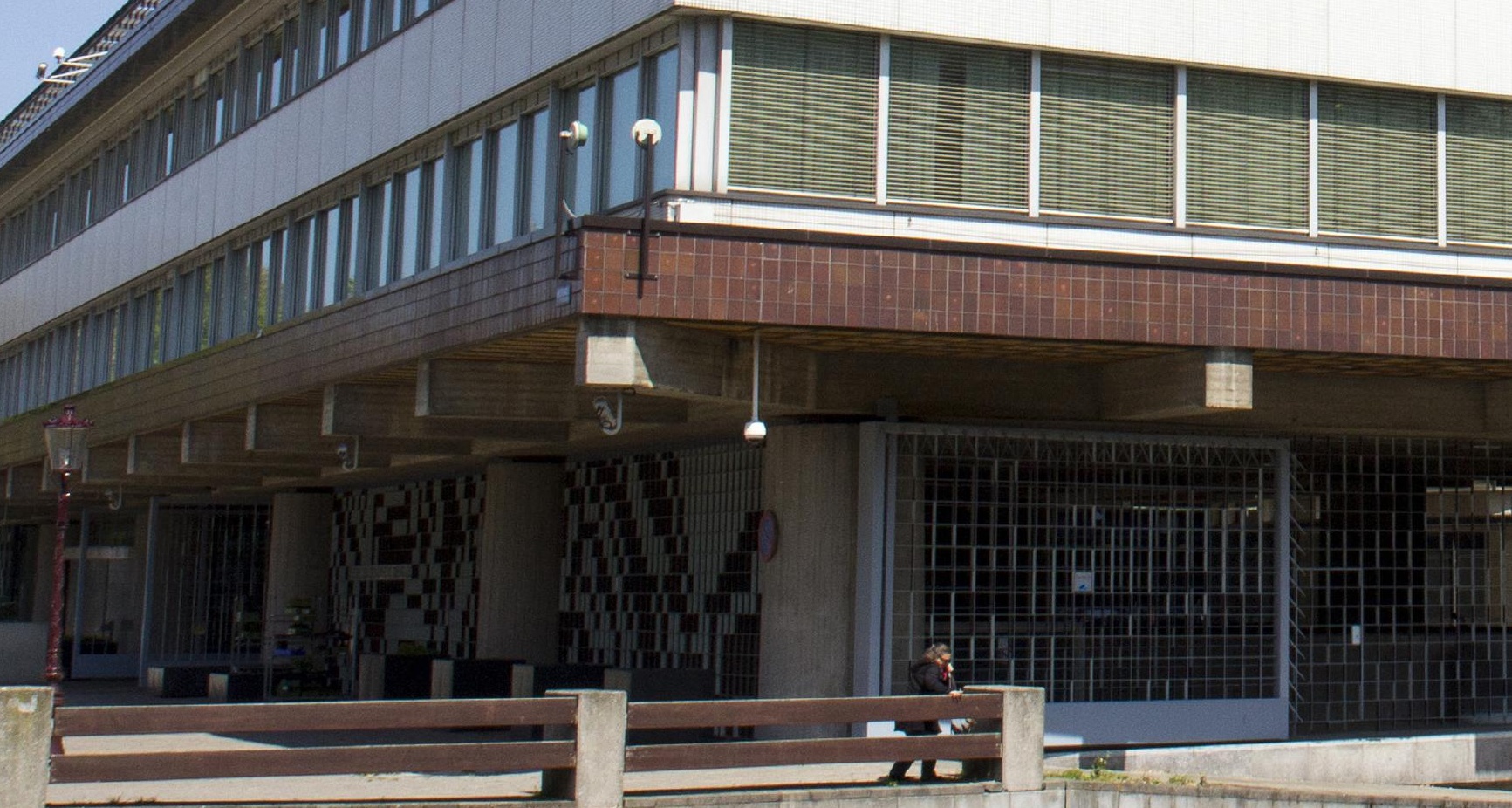

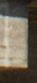
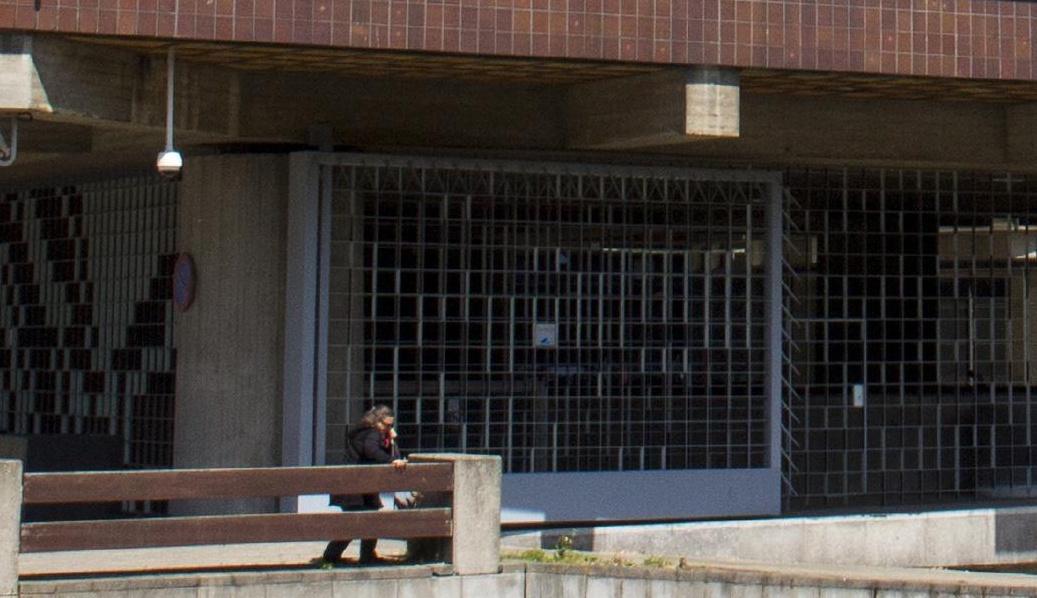